\title{
The transition to IPSAS standards: the extent of adoption and the influence of institutional, contingency and economic network factors
}

\author{
Amel Amiri ${ }^{\mathrm{a}}$ and Sarra Elleuch Hamza ${ }^{\mathrm{b}, 1}$ \\ ${ }^{a}$ IHEC Institute, Carthage, Tunisia \\ ${ }^{b}$ ISCAE Institute, LIGUE, Campus University 2010, Manouba University, \\ Tunisia
}

\begin{abstract}
Research Question: the study identifies the reasons behind the country choice between different IPSAS adoption approaches. Motivation: Our motivation is guided by the growing interest in financial reporting for the public sector. In this sense, this study is distinguished from the former articles by increasing the extent of adoption into four categories instead of dividing it into two classes (adopters vs. non-adopters). Besides, this paper differs from previous studies by relying jointly on not only the institutional and the contingency but also the economic network factors to explain countries' decision to adopt IPSAS. Idea: In this paper, we deal with two objectives. Our first aim is to propose a new measure of the extent of the adoption of International Public Sector Accounting Standards (IPSAS). On the other hand, our second aim is to identify the factors influencing the IPSAS adoption decision. Data: Different sources are used: the IFAC's websites, the ACCA's website, the big audit firms websites, international banks and countries Ministries of Finance websites. Tools: Fifteen explanatory variables were retained to explain the variation in the extent of IPSAS adoption of 84 countries. Principal Component Analysis (PCA) is adopted to summarize the huge quantity of information presented in the explanatory variables. Then, a multinomial logistic regression is used to test our hypotheses. Findings: Our main results show that coercive and mimetic institutional pressures positively affect the adoption of cashbasis IPSAS. Whereas, the good economic governance has a significantly impact on the full accrual-basis IPSAS adoption. The close of economic relationships with international partners pushes countries to adopt modified accrual-basis IPSAS.
\end{abstract}

${ }^{1}$ Corresponding author: Department of Accounting and Finance, ISCAE Institute, LIGUE, Campus University 2010, Manouba University; email address: sarra.ell@ iscae.rnu.tn. 
Contribution: These findings help non-adopting countries that intend to move in the IPSAS direction to predict the form of their future adoption.

Keywords: Cash-basis IPSAS, Modified cash/accrual basis IPSAS, Full accrualbasis IPSAS, Institutional factors, Contingency factors, Economic network factors.

\section{JEL codes: M41}

\section{Introduction}

In the 1980s and 1990s, a traditional budgetary accounting system in the public sector is considered an inappropriate framework to face the challenges of new public management (Lapsley, 1999). Driven by this concept, many countries initiated structural changes in their accounting system. By introducing the accrual notion as an innovation in government accounting, these countries tend to shift from cash to accrual accounting. The emergence of international IPSAS is the most significant development in the implementation of accrual accounting in the public sector (Stucliffe, 2003). These standards fill the gaps in budget accounting by providing appropriate accounting records for assets, liabilities and inventories.

The objectives of this transition are numerous. First, the adoption of IPSAS enhances the comparability of public financial reporting information between countries by facilitating the convergence of different accounting systems. Second, it improves the transparency and accountability of public services (Lapsley, 1999; Ball, 2012). But the main objective is to evolve the public management philosophy towards a more entrepreneurial approach focused on the performance (Tanjeh, 2016).

The adoption of IPSAS can be voluntary or mandatory. However, in all cases, there is flexibility and a margin of freedom to choose the form of adoption. Currently, many countries have adopted IPSAS, while others have adapted to the implementation context. In this sense, various authors such as Pina \& Torres (2003), Christiaens et al. (2010), Adhikari and Mellemvik (2010) explored the adoption of IPSASs in many countries and released comparative studies in the public sector. They identified the different kinds of adopting accounting system across nations and analyse their degree of compliance with IPSAS standards.

Some countries are only harmonized with cash basis IPSAS. Others governments limit their adoption to the cash basis IPSAS but state that they plan to introduce the accrual basis of accounting within the next few years. However, others countries use a modified accrual accounting basis by applying some basic elements of the 
accrual accounting system. Finally, some jurisdictions implement full accrual IPSAS.

Previous studies simply identified whether IPSAS standards have been implemented, regardless of whether these standards are in line with a cash or accrual accounting (e.g. Sellami \& Gafsi, 2019)." Indeed, most of them only focus on the commitment accounting ignoring that the IPSAS Board also publishes standards on a cash basis.

Unlike these previous studies, our objective is not to better understand the influencing factors of countries' decision to adopt IPSAS. The main purpose of our study is to examine the factors motivating the adoption of the accrual-based IPSAS instead of the cash basis IPSAS and vice versa. Our research is the first to identify the extent of IPSAS adoption more comprehensively.

In particular, we are interested to seek when the cash basis IPSAS is an appropriate reform for a country and when the accruals one is more relevant. Hence, identifying the reasons behind the country choice between different adoption approaches may provide an answer to this question.

Our study examines the explanatory factors affecting the cash/accruals basis IPSAS adoption decision. We not only examine the impact of contingency factors that may influence the extent of IPSAS adoption, but also the institutional as well as the economic network factors. The impact of economic network factors is ignored in previous studies. Most of them focused on contingency factors (Caba et al., 2009; Tanjeh, 2016; Ben Amor \& Damak Ayadi, 2019). Some others researchers studied the influence of institutional and environmental factors on the IPSAS adoption decision (Sellami \& Gafsi, 2019; Rajib et al., 2019).

Our sample includes all countries that opt for accounting harmonization according to IPSAS. After eliminating countries due to the unavailability of information, our final sample is composed of 84 countries. We class these countries into 4 forms, ranging from the simplest (cash-basis IPSAS) to the most complex form (full accrual-basis IPSAS). While previous literature limits the migration to IPSAS to only two modalities: "adoption vs non-adoption" or "full or partial adoption vs no adoption".

Since our model includes 12 quantitative variables, principal component analysis is conducted on these variables to synthesize and facilitate the analysis. Subsequently, we perform a multinomial logistic regression to verify our assumptions.

The results confirm the effect of contingency and institutional factors and initiate the effect of the economic network. These results show that coercive and mimetic institutional pressures significantly and positively affect the cash-basis IPSAS 
adoption. While the contingency factors as information transparency, fiscal pressures and education have a significant and positive impact on the full accrualbasis of IPSAS adoption. Finally, the effect of the economic network contributes, through international trade, to increase the implementation of modified accrualbasis IPSAS adoption.

This study, which covers the international context, has practical implications since it provides international financial institutions, such as World Bank (WB) and International Monetary Fund (IMF), answers about how well the economies receiving international assistance are meeting their expectations for IPSAS adoption.

The following of this study is organised as follows. The next section provides a theoretical overview to explain the different modalities of harmonization of accounting standards according to IPSAS as well as the factors influencing accounting reforms. The third section illustrates the methodology used in this study. While the fourth section presents the empirical results. The last section is devoted to the discussion and conclusion.

\section{The extent of IPSAS adoption: theoretical study and factors influencing}

Before developing the reasons behind the countries' decision to choose the form of IPSAS adoption, we give an overview of the degree of IPSAS adoption in the world.

\subsection{Overview of the extent of IPSAS adoption}

A few studies examine the extent of applying IPSAS in the world. The majority of studies distinguish the countries adopting IPSAS from non-adopters. Studies explored the degree of their adoption are relatively limited. This extent varies between countries according to these particular conditions.

Many countries reacted to the recent reforms promoting by the International Public Sector Standards (IPSAS) Board. There is a strong trend toward their adoption across all continents and especially in Asia, Latin America and Africa. Some of the countries are in the process of adopting IPSAS. Others apply the cash basis IPSASi and others else adopt accrual accounting standards consistent with IPSAS. These countries are free to choose between these alternatives to report their statements although it is easier to translate from cash basis to accrual one. It seems that accrual accounting gained universal acceptance in public sector accounting systems and only a few countries still use the cash one (Brusca, 2016). 
Anglo-America countries generally adopt full accrual accounting, which is consistent with IPSAS requirements. Indeed, these countries apply New Public Management reforms, which recommend governments to prepare their financial reports on the accrual basis (Pina \& Torres, 2003). For developed countries like the United Kingdom, the main reason for using the accrual IPSAS standards is their similarity with IFRS guidelines (Pilcher, 2011; Brusca et al., 2013).

Even developing countries started to adhere to full IPSAS adoption. In LatinAmerica countries such as Colombia and Chile, the aim of moving to full IPSAS is to modernize accounting systems and to improve both transparency and quality of financial reporting (Brusca et al., 2016). In these countries, the accrual basis of accounting following IPSAS is seen as an anti-corruption tool (Christiaens et al., 2014).

Eastern European countries also seek aggressively to adopt full accrual-based IPSAS or adapt them to adhere to the European Union (Christiaens et al., 2014). Few African countries are involved in the process of this reform. Tanzania is the front-runner in the adoption of accrual-based IPSAS even if it faces various challenges (ACCA, 2017).

However it is mainly the developing countries that choose a cash accounting system that is qualified as less costly to implement (Chan, 2006). In particular, South Asia countries are limited to cash-basis IPSAS (Adhikari \& Mellemvik, 2010). Arabic countries such as Iraq and Jordan also opt for cash accounting. Only Kuwait seems to be making real efforts to implement more IPSAS standards (Abushamsieh et al., 2014). Recently, Tunisia and Morocco follow these Arabic countries by opting for elements of accruals-basis IPSAS.

Developing countries, which are more dependent on international resources, are pushed to apply the conditions imposed by international financial institutions. The latter forces them to reform their public accounting system according to the IPSAS standards. This is the case of many African countries (ACCA, 2017). In particular, East African countries signed in 2013 a protocol to harmonize financial reporting across the region by adopting IPSAS standards. Their bureaucratic and centralized systems do not help them to modernize their accounting traditions and transit to an accrual accounting system (Christiaens et al., 2014).

Besides, the adoption of IPSAS in these countries often needs an investment in education and training in accrual accounting skills. Since their governments have limited resources, it is difficult in these countries to translate to accrual accounting, which is close to IPSAS (Chan, 2006). Between the two extremes of cash and full accrual accounting standards, there is a variety of degrees of recognition accrual. Because it is difficult to fully adopt the IPSAS standards, many countries moderated some rubrics of accrual accounting and so applied modified accrual 
accounting. Some of them started by recognizing current liabilities, others added long-term liabilities and others reported in addition to operating fixed assets (Chan, 2006).

In general, European Continental countries adhere to modified accrual accounting. For example, the Spanish standard-setter combines both private accounting standards and IPSAS into one set of new standards to adapt existing Spanish public accounting to international one (Brusca et al., 2013).

As for European Continental countries, many Asian, African and Latin American countries have chosen the same alternative. Indeed, because of the complexity of financial instruments and the difficulty in valuing particular assets, Malaysia has partially adopted IPSAS. Sri Lanka makes the same decision since its standards do not cover revenue from non-exchange activities and employee benefits. South Africa that had difficulties in recording infrastructure assets, receivables and revenue preferred a modified accrual accounting. It is waiting for improvements to the IT infrastructure to support all IPSAS standards. The lack of new technologies also impeded Guatemala from moving to full accrual adoption (ACCA, 2017).

Because of these difficulties, some countries do not find any advantages to translate to modified accrual accounting. Rather they prefer the modified cash basis of accounting. For example, because of the unavailability of information on assets and liabilities, India maintains the cash basis IPSAS and declared its intention to move to the accrual basis of accounting in the future (Adhikari \& Mellemvik, 2010).

\subsection{Factors influencing the extent of IPSAS adoption}

Prior literature examined many factors influencing the countries' decision to adopt IPSAS. External and internal factors are the main factors identified to explain this decision. Institutional theory and the economic network theory evoke the external factors to the country. The different pressures exercised by external bodies are underlined by the institutional theory whereas external incitations are highlighted by the economic network theory. Internal factors to the decision of IPSAS adoption are identified by the contingency theory.

The effect of these factors on the form of IPSAS adoption is rarely analysed in the literature. To our knowledge, our study is the first one to investigate this effect. Besides, we analyze the effect of economic network factors that does not treated by previous studies. 


\subsubsection{The impact of institutional pressures on the extent of IPSAS adoption}

Institutional theory is employed to better understand various organizational and individual accounting practices and activities. Under this theory, there exists outside organizations, a set of values, norms and models that influence their structures and their management mode (Meyer \& Rowan, 1977). In this way, organizations are faced with pressures and must react to them.

Pressures arise from a variety of factors. DiMaggio and Powell (1983) identify three main types of pressure supporting isomorphic institutional change. The first type is the coercive isomorphic that arises from "political influence and the problem of legitimacy". In particular, developing countries, receiving external financial support, are encouraged to introduce IPSAS into their accounting systems by international coercive institutions outside the economy such as the World Bank or the IMF (Abushamsieh et al., 2014; Caba et al., 2009; Rakoto \& Lande, 2008). Indeed, international donors exert external pressures on the economies benefiting from public development aid to adopt international best practices as part of their recommendations to improve the accountability and transparency of public sector entities. In particular, these financial institutions require the adoption of accrual accounting standards based on IPSAS as a condition for their financial assistance instead of cash basis IPSAS (ACCA, 2017).

The second type of institutional isomorphic is related to mimetic pressures. In a context of high uncertainty, organizations tend to reproduce successful organizational practices by other entities, and therefore to imitate them. Mimicry can reduce this uncertainty by adopting existing methods, thus minimizing the risk. Following this logic, economies tend to imitate successful experiences of organizations that have similar characteristics by adopting best practices such as IPSAS (DiMaggio \& Powell, 1983). This mimetic pressure seems to be more pronounced in small countries to gain credibility (Adhikari \& Mellemvik, 2010).

Besides, external mimetic pressures can arise from economic globalization, international positioning and the increasing competition. These pressures push countries to change their public sector accounting system. In this regard and at the beginning of the capitalist era, some of the Eastern European countries change their accounting systems by adopting the full IPSAS one to adhere as a member of the European Union (Christiaens et al., 2014). In particular, Estonia is a country that undergoes a transition from a communist economy to a market one. It is one of the few European countries that apply full accruals standards following IPSAS (Argento et al., 2018).

The last type of institutional isomorphic is the normative isomorphism, which stems from professional organizational behaviour (DiMaggio \& Powell, 1983). It reflects the influence of these organizations on the adoption of accounting 
standards. Indeed, International Public Sector Accounting Standards Board (IPSASB), which is an independent standard-setting body, strongly encourages each country to migrate to IPSAS (Benito et al., 2007; Brusca \& Martínez, 2016). Its role is to harmonize between different governmental Accounting systems.

The International Federation of Accountants (IFAC) also urged its member countries to integrate international accounting standards into their national jurisdictions (Ali, 2005). According to this body, cash-based accounting does not allow greater comparability between different economies and does not improve decision-making processes. In general, international accountancy organizations promote the use of accrual-based IPSAS. Hence, the degree of representation by professional accounting bodies can explain international differences in accounting practices (Christiaens et al., 2014). The more an economy is represented in IFAC, the greater will be the extent of IPSAS adoption.

\subsubsection{The impact of contingency factors on the extent of IPSAS adoption}

Lüder's (e.g. 1992) work showed that the introduction of a more informative accounting system depends on contextual conditions. This author adapted the theory of contingency to the public sector to explain how the national environment influences the evolution of public accounting. His contingency model is used to elucidate the reasons for the transition from the traditional government accounting system to accruals one. It is composed of four elements. The first and the second elements are the users and producers of public accounting information, which their attitudes are affected by this accounting innovation. Their behaviours depend fundamentally on stimuli and implementation barriers, which are the third and fourth elements of the contingency model.

A set of stimuli such as the corruption is evocated by the literature. Several studies have confirmed that countries with lacked rigorous public accounting systems have a high level of corruption (Christiaens et al., 2014). They undertake significant reforms to improve transparency and fight corruption. They tend to disclose useful information to interested parties, building thus a trustful relationship. Atuilik (2016) found that unlike developed countries, the levels of corruption in developing countries that have adopted IPSAS are lower than those of nonadopters. By opting for high levels of IPSAS, they can profit from the benefits of these standards. In particular, Chan (2006) underlined the superiority of accrual accounting compared to cash accounting in terms of fighting corruption.

Furthermore, Lüder (1992) pointed out that financial problems provided the stimulus for reform of public sector accounting systems. Unlike financially independent countries, governments with a heavy burden of debt tried to improve their public management to reduce their public debts. They tend to apply public international accounting standards (Opanyi, 2016). Specifically, after the severe 
debt crisis in Greece, the government moved to the modified cash basis as an interim step towards accrual accounting. According to this form of IPSAS adoption, transactions are recognized under a cash basis. Besides, it takes into account liabilities and financial assets. With this type of IPSAS, the Greek government tries to make information more informative to support privatization decisions (Cohen et al., 2015). In general, the recent global financial crisis pushes many governments to report all their assets and liabilities by adopting full IPSAS (Izedomni \& Ibadin, 2013). However, most of the South Asian countries only align with cash-basis IPSAS due to difficulties to implement accrual-basis IPSAS (Miraj \& Wang, 2018).

In addition, Lüder (1992) underlined that individuals with higher educational levels require more disclosure of relevant and detailed financial information. This is explained by the concept of socio-economic status, introduced by Chan and Rubin (1987). According to this concept, individuals are not equivalent on socioeconomic status. Lüder (1992) added that the higher the socio-economic status is, the greater is the information citizens' expectations of public sector financial reports. Evidence has shown that the level of IPSAS adoption is positively associated with the level of education, qualification and specialist training of accounting in Cameroon (Tanjeh, 2016).

The size of the government is another stimulus highlighted by Lüder (1992). As the size of a country increases, administrative and technical problems linked to tax revenues rise. Therefore, the interest in setting up control systems is increasing. Implementing a new accounting system, as standardized procedures, can reduce monitoring costs. Thus, we can assume that large governments are more likely to produce quality financial reports opting for a higher level of IPSAS adoption. However, Ouda (2010) who proposed several factors to support the implementation of accrual accounting, pointed out that the size of jurisdiction is considered as an implementation barrier. He underlined that the accounting reform is easier for small countries than for bigger ones.

The flexibility of a legal system is another contingency factor identified by Lüder. According to Grossi and Soverchia (2011), nation accounting systems can be classified into Continental and Anglo-Saxon accounting systems. The Continental accounting model relies on the civil legal system, which is connected with a more bureaucratic design. However, the Anglo-Saxon accounting model is more associated with the common law system. It is considered as a flexible legal system that promotes accounting innovation in the public sector. Anglo-Saxon countries so have a modern accounting system based on accruals rather than cash (Rossi et al., 2014). In addition, the European Continental countries are also covered by a set of harmonized accounting standards for the European countries (EPSAS). These countries are then less motivated to adopt IPSAS standards (Ben Amor \& Damak Ayadi, 2019). However, the translation of these standards by the IPSAS Board into 
Portuguese and Spanish languages facilitated the adaptation of IPSAS standards by Portugal and Spain (Jeorge et al., 2019).

Other external stimuli are added to the Lüder model. The characteristics of the political-administrative system and the social environment of the country are also considered as contextual variables and are categorized as stimuli (Chan, 1996).

Precisely, through the literature review, it appears that the fiscal pressure is considered as a contingency factor. Benito et al. (2010) assumed that the greater the tax burden per capita is, the greater the demand by citizens for efficient information will be. Taxpayers become more incentive to understand how their taxes were spent. They "have the right to seek accountability from the government that manages their resources" (Tanjeh, 2016). The fiscal pressure is so connected to the attitude of information users toward more informative forms of public accounting systems. In this sense, Kartiko et al. (2018) found a positive relationship between fiscal transparency and accrual-based IPSAS implementation level. They so underlined that accrual-basis IPSAS improves fiscal transparency.

Inflation is another contingency factor. IPSAS standards guide assessing the nonmonetary items in high hyperinflationary economies. Indeed, to improve the comparability of financial statements with non-inflationary countries, IPSAS 10 provides for countries with high inflation, a set of complex methods to re-estimate non-monetary items based on a change in a price index. Due to the complexity of applying such accounting standards for the public sector, many countries with the highest inflation can be reluctant to adopt such standards. Thus, economies that are identified as hyperinflationary prefer cash than accruals basis IPSAS. Using case studies, Mhaka (2014) and Javed \& Zhuquan (2018) revealed that hyperinflationary economies such as Zimbabwean and Pakistan appreciate the necessity of cash-basis IPSAS and find more benefits for application of these standards.

Finally, prior literature sheds light on the interaction between the economic environment and accounting. In this context, Sour (2012) focuses on the important role played by economic growth in the adoption of accrual-basis IPSAS. Indeed, she raises the need for the valuation of fixed assets and depreciation to enhance the country's economic development. The use of accrual accounting systems helps to produce more accurate information about the performance of public administration in charge to promote economic growth. Babatunde (2013) found a significant effect of adopting the accrual basis IPSAS on transparency and accountability in the Nigerian public sector. Sellami \& Gafsi (2019) introduced the economic growth as a control variable to identify the factors influencing the IPSAS adoption. Hence, high rates of economic growth have a significantly positive impact on countries' decision to choose the accrual-basis of IPSAS form. 


\subsubsection{The impact of economic network factors on the extent of IPSAS adoption}

According to the economic network theory, the advantages of goods or services, which depend on the network, stream from the participants on the same network. Partners such as individuals, groups or countries interact with each-other. This interaction produces a synergy that increases the wealth of all partners (Hamisi, 2012). Jeorge et al. (2019) view international public accounting standards as a network-dependent product. Under this theory, the interaction between organisations influences the choice of accounting standards in the public sector. In particular, it puts in evidence the effect of regional trends. A country is more likely to implement accrual-based IPSAS when other countries in its geographic region adopt these same standards (Opanyi, 2016). In this sense, the adoption of IPSAS is considered as a product with network effects that benefit the whole community.

The IPSAS can be adopted not only due to its network benefits but also due to its direct benefits. According to Opanyi (2016), the direct benefits are inherent to the economic and political net value of IPSAS over national standards. Indeed, these authors argued that the benefits of adopting international public accounting standards can be explained by the close of economic relationships with partners who have already adopted these standards. In particular, this theory puts in evidence the effect of import and export transactions with partners of goods and services and unilateral transfers on the implementation of accrual-based IPSAS.

Moreover, to attract foreign investment, the host country has an interest in adopting a uniform accounting framework to that of the country of origin. In general, in more globalized economies, the foreign investment and trade are highly increased. To increase the magnitude of its international economic relations, standard-setters of a given country should provide relevant financial reporting recognized worldwide (Hamisi, 2012). So, it implements the same partner state standards as well. Since IPSAS standards are considered as the more appropriate to enhance the quality of financial information in the public sector, the extent of IPSAS adoption of a country is influenced by the adoption level of its trade partners.

\section{Data and methodology}

\subsection{Sample and study period}

The initial sample consisted of all countries around the world that adopted IPSAS standards. The sample is selected from the IFAC's website available at: https://www.ifac.org/what-we-do/global-impact-map/country-profiles. This website provides information about the IPSAS adoption status for each jurisdiction. When the data are unavailable, we refer to another IFAC website available at: https://www.ifac.org/system/files/publications/files/IPSAS_Adoption_Government s.pdf. 
The transition to IPSAS standards: the extent of adoption and the influence of institutional, contingency and economic network factors

Although the total sample includes 198 countries from around the world, our final sample only includes 84 countries. Indeed, 40 nations are not IPSAS-adopters and 61 countries do not present explicit information. Besides, due to the problem of data availability about the form or the year of IPSAS adoption, 13 countries are excluded. Three countries are changing their adoption status over the time. We therefore identified 87 observations. Table 1 summarises our final sample selection.

Table 1. Sample selection process

\begin{tabular}{lc}
\hline \multicolumn{1}{c}{ The total number of countries: } & 198 \\
$\bullet \quad \begin{array}{l}\text { Non Adopters' countries } \\
(-) \text { Countries with imprecise information on the IPSAS }\end{array}$ & $(40)$ \\
$\quad$ adoption status & 97 \\
\hline$=\quad$ Initial sample & $(8)$ \\
\hline$(-) \quad$ Countries with missing information on the year of IPSAS adoption & $(5)$ \\
$(-) \quad$ Countries with missing information on the level of IPSAS adoption & 84 \\
\hline$=\quad$ Final sample & 3 \\
\hline$(+) \quad$ Countries that are changing their IPSAS status & 87 \\
\hline$=\quad$ Total observations & \\
\hline
\end{tabular}

Our data collection was carried out from the website accessed in April 2020 to identify the IPSAS adoption commitment. It should be noted that the sample is classified according to the adoption status until the year 2019. The first country takes the IPSAS commitment decision in 2001 and the last one in 2018 (see appendix A).

\subsection{Measurement of variables and data sources}

\subsubsection{Measurement of dependent variables}

Our study focuses on the form adopted by the country when it chooses IPSAS standards. In reality, the IPSAS adoption decision can take several forms. By examining the IFAC's website, we noticed that there are different modalities regarding the IPSAS adoption decision. We were able to classify them into 4 forms, coded from 1 to 4 :

1: if the country opts for IPSAS based on cash accounting;

2: if the country chooses cash accounting and subsequently accrual accounting inspired by IPSAS;

3: if the country opts for accrual accounting inspired by IPSAS. In this sense, not all accruals based IPSAS are adopted or the accruals based IPSAS are adopted for only some public sector entities;

4: if the country opts for all accrual accounting following IPSAS. 
These four modalities are classified according to the degree of concordance with the IPSAS. This classification is explained by the high quality of IPSAS standards and the superiority of accrual accounting over cash accounting. This superiority is justified by the quality and quantity of the information provided. Hence, the dependent variable is a multinomial variable that takes into account the order of these four categories.

To collect data related to our dependent variable, we used different sources. As discussed above, we used first the IFAC's websites. If these sources do not mention the form or the year of adoption, we looked then at other sites like the ACCA's ${ }^{\text {ii }}$ website, the big audit firms ${ }^{\text {iii }}$ websites, international banks ${ }^{\text {iv }}$ and countries Ministries of Finance websites.

\subsubsection{Measurement of independent variables}

As discussed above, many independent variables can influence the extent of IPSAS adoption. The first is linked to the coercive isomorphic. Following Judge et al. (2010) as well as Abushamsieh et al. (2014), we proxy for donor pressures with the level of foreign aid. It measures the weight of foreign aid in a given economy by computing the proportion of foreign aid as a percentage of the gross domestic product (GDP). Foreign aid includes grants and concessional loans.

The second independent variable measures the mimetic isomorphism. According to Judge et al. (2010), the degree of external openness is measured by import penetration. In our study, we adopt the same proxy, namely the amount of import penetration as a percentage of GDP. According to the World Bank, this ratio represents the best proportion of imports in a given economy.

Unlike Judge et al. (2010) and Sellami and Gafsi (2019), we cannot proxy for the third institutional isomorphism with the education level of a nation because this measure does not necessarily reflect an indicator of the development of accounting profession. For this reason and following Kossentini and Ben Othman (2014), we use IFAC membership as an alternative proxy for normative isomorphism. Indeed, IFAC organization urges its member countries to adopt IPSAS into their national jurisdictions. It is expressed as the number of professional accounting bodies that represent a given economy in IFAC.

The fourth independent variable is the education level. Since the adoption of IPSAS requires a high level of education to understand and make use of such standards, we do not proxy the level of education by secondary education attainment as chosen by Judge et al. (2010). Rather, we opt for the percentage of enrollment in tertiary education. Precisely, the total enrollment is divided by the total population of the age group corresponding to this level of education. 
The most common way to measure economic growth, which is the fifth variable, is the annual growth of the Gross Domestic Product (Archambault \& Archambault, 2009; Sellami \& Gafsi, 2019). We use the same measure since it is considered a good indicator that represents the total value added of goods and services produced.

The sixth independent variable is the economy's debt. We choose the gross debt of the general government as a percentage of GDP. This choice, which is available for a larger sample of countries, is justified by the fact that this measure is calculated on an international basis. It is currently the key indicator in the financial health analysis of the public sector, the target of our research. Gross debt does not only represent debts contracted by the state, but insurance, pensions and guarantees as well as other accounts payable are also taken into account (OECD, 2016).

The fiscal pressure representing the seventh variable is measured by the weight of taxes in the national economy. It corresponds to the total tax revenue collected, expressed as a percentage of GDP. It so includes direct taxes collected by the public treasury, indirect taxes, direct tax collections, local taxes and social security contributions.

Due to the unavailability of data for several countries, we cannot follow Shima and Yang (2012) or Archambault and Archambault (2009) to measure the eighth variable by inflation as a percentage of GDP. We so opt for the annual percentage change in a Consumer Price Index (CPI), which is the most well-known indicator.

To measure the ninth variable, previous research used two indicators of corruption: the World Bank's Worldwide Governance Indicator (WGI) in terms of anticorruption and the Corruption Perception Index (CPI). The WGI measures corruption in both public and private sectors, as perceived by experts and opinion polls. While the CPI only measures corruption perceived by experts in the public sector. For this reason, we retain the IPC because it deals with the public sector which is the target of our research.

The tenth variable is the size of the government. According to Downes and Mamingi (2001), there is no consensus on the best measure of government size. They note that size can be measured by one or a combination of the following indicators: GDP, population and area. Following Lüder (1992), size can be represented by population in absolute terms or by population density. Clements et al. (2010) use market capitalization as a measure of government size. Nevertheless, measures such as market capitalization and GDP have limits since they describe the economy of a country more than its size. Therefore, we used the population density per $\mathrm{km}^{2}$ as a measure of government size. 
The eleventh variable is a dummy variable which equals one if the country has a common-law legal system and zero otherwise. The effect of the economic network factors is measured by three variables. The first variable is the foreign investment, which is measured by foreign direct investment, net inflows. This indicator represents the balance of investment inflows and outflows. It is divided by the gross domestic product. The second economic network factor is international trade. The World Bank defines trade balance as a major indicator of international trade. Due to the unavailability of trade balance data for some countries and some years, we retained the current account balance. It is expressed as the percentage of GDP to take into account the importance of the country's economy. This measure is defined by the World Bank as another indicator of the commercial health of a country vis-à-vis its trading partners.

The last economic network variable measures the country's belonging to a specific region. Countries are ranked with reference to the World Bank' countries' classification by region, using the following link: https://datahelpdesk. worldbank.org/knowledgebase/articles/906519-world-bank-country-and-lendinggroups. This variable will be coded as follows: 1 Latin America and the Caribbean; 2 East Asia and Pacific; 3 South Asia; 4 Sub-Saharan Africa; 5 Middle East and North Africa; 6 Europe and Central Asia; 7 North America. To collect data related to the independent variables, we consulted different sources such as the World Bank's website, IMF's website, World Factbook's website, Transparency International's website and IFAC's website (see Appendix B).

\subsection{Principal component analysis: Results and formulation of hypotheses}

In our study, several variables maybe used to predict the nominal dependent variable. Among them, twelve are quantitative variables. Given a large number of variables, a factorial principal component analysis is conducted on the quantitative variables. The objective is to obtain a minimum of factors retrieving the maximum of information to form groups of variables. The main advantage of this method is its possibility to synthesize and facilitate the analysis by replacing the quantitative variables initially correlated with uncorrelated factors. Going through factor analysis is often necessary to avoid multi-collinearity bias in a regression. By identifying the principal factors, we can formulate more defined hypotheses.

Before choosing the factorial solution, we release at the beginning the KMO index and Bartlett's Test to verify the null hypothesis of no correlation which assumes that the correlation matrix between the twelve variables is a unit matrix. If this hypothesis is accepted, the factor analysis should not be carried out. Thereafter, we check the quality of variables representation which must be greater than 0.50 . 
The transition to IPSAS standards: the extent of adoption and the influence of institutional, contingency and economic network factors

To synthesize data about quantitative variables, a factorial principal components analysis was conducted. This analysis shows the existence of significant correlations between the variables. Indeed, the KMO index is 0.567 , which is within the interval $[0.50,0.59]$. According to this value, the factorization quality in our study is mediocre. Bartlet's Test indicates that the risk of making a mistake by rejecting the null hypothesis is equal to 0 . Therefore, there is a correlation between the 12 variables and we must carry out the factor analysis.

Panel A of Table 2 presents the results of the quality representation of the variables used in the factor analysis. It shows that all variables, except for the foreign investment variable $(0.244)$, respect the limit of 0.5 and are well represented on the factor map. Therefore, we can conclude that the quality of the factor analysis is good and that only the foreign investment variable should be removed. Panel B presents the same results without the foreign investment variable.

Table 2. Result of the quality of variables representation

\begin{tabular}{lcc}
\hline Panel A: Result of the quality of all variables & & \\
\hline & Initial & Extraction \\
\hline Corruption & 1.000 & 0.713 \\
Coercive pressures & 1.000 & 0.742 \\
Economic Growth & 1.000 & 0.627 \\
Debt & 1.000 & 0.711 \\
International commerce & 1.000 & 0.621 \\
Tax pressures & 1.000 & 0.526 \\
Education & 1.000 & 0.630 \\
Inflation & 1.000 & 0.675 \\
Normative pressures & 1.000 & 0.611 \\
Foreign direct investment & 1.000 & $\mathbf{0 . 2 4 4}$ \\
Mimetic pressures & 1.000 & 0.652 \\
Size & 1.000 & 0.543 \\
\hline Panel B: Result of the quality of all variables except for the foreign direct investment \\
\hline & Initial & Extraction \\
\hline Corruption & 1.000 & 0.727 \\
Coercive pressures & 1.000 & 0.736 \\
Economic Growth & 1.000 & 0.666 \\
Debt & 1.000 & 0.710 \\
International commerce & 1.000 & 0.640 \\
Tax pressures & 1.000 & 0.590 \\
Education & 1.000 & 0.632 \\
Inflation & 1.000 & 0.674 \\
Normative pressures & 1.000 & 0.606 \\
Mimetic pressures & 1.000 & 0.670 \\
Size & 1.000 & 0.538 \\
\hline
\end{tabular}


According to Kaiser's criterion, only theeigenvalues of the first four factors are more than unity. Their variance explains $65.348 \%$ (see Table 3). So, the plan formed by the first four factors makes it possible to recover $65.348 \%$, by replacing the 12-dimensional space with a four-dimensional plan.

Table 3. Results of the selected factors

\begin{tabular}{ccccccc}
\hline & \multicolumn{3}{c}{ Initial eigenvalues } & \multicolumn{3}{c}{$\begin{array}{c}\text { Extraction Sum of squares } \\
\text { of the selected factors }\end{array}$} \\
\cline { 2 - 7 } Component & Total & $\begin{array}{c}\text { \% of } \\
\text { variance }\end{array}$ & $\begin{array}{c}\text { \% } \\
\text { cumulated }\end{array}$ & Total & \% of variance \% cumulated \\
1 & 2.399 & 21.807 & 21.807 & 2.399 & 21.807 & 21.807 \\
2 & 2.136 & 19.418 & 41.225 & 2.136 & 19.418 & 41.225 \\
3 & 1.361 & 12.372 & 53.597 & 1.361 & 12.372 & 53.597 \\
4 & 1.293 & 11.751 & 65.348 & 1.293 & 11.751 & 65.348 \\
5 & 0.942 & 8.564 & 73.913 & & & \\
6 & 0.804 & 7.307 & 81.220 & & & \\
7 & 0.592 & 5.386 & 86.606 & & & \\
8 & 0.508 & 4.615 & 91.221 & & & \\
9 & 0.366 & 3.331 & 94.552 & & & \\
10 & 0.321 & 2.920 & 97.472 & & & \\
11 & 0.278 & 2.528 & 100.000 & & \\
\hline
\end{tabular}

After extracting 4 components, we use the matrix of components after Varimax rotation to group the correlated variables with the corresponding factors. The results are presented in Table 4.

Table 4. Component matrix results after rotation

\begin{tabular}{lrrrr}
\hline & \multicolumn{5}{c}{ Components } \\
\hline Corruption & $\mathbf{1}$ & $\mathbf{2}$ & $\mathbf{3}$ & $\mathbf{4}$ \\
Tax pressures & 0.789 & 0.120 & 0.268 & -0.134 \\
Inflation & 0.691 & 0.159 & -0.275 & -0.106 \\
Education & -0.653 & 0.272 & -0.097 & -0.405 \\
Debt & 0.536 & -0.054 & 0.246 & -0.531 \\
Coercive pressures & 0.072 & 0.827 & 0.140 & -0.022 \\
Mimetic pressures & -0.439 & 0.698 & -0.218 & -0.096 \\
Normative pressures & 0.310 & 0.662 & -0.365 & 0.040 \\
International commerce & 0.086 & 0.114 & 0.763 & -0.057 \\
Economic Growth & 0.024 & -0.308 & 0.736 & 0.057 \\
Size & -0.107 & -0.140 & -0.054 & 0.795 \\
\hline & 0.192 & 0.352 & 0.314 & 0.528 \\
\hline
\end{tabular}

a. The rotation converged in 8 iterations. 
Examining the factor scores matrix rotated easily reveals that four variables are significantly correlated with the first factor, which are corruption, tax pressures, inflation and education. Such variables constitute indicators of a country's economic governance (Ndinga, 2002). Countries with high levels of transparency and education as well as economies, which are not deemed highly inflationary, prefer to adopt full accruals basis IPSAS. Indeed, as mentioned in the review literature section, governments tend to orient their national accounting system towards transparency in the presentation of public financial information (Brusca et $a l ., 2016$ ), especially when the full accruals basis IPSAS is considered as an anticorruption tool. We suggest that countries having good indicators of economic governance are more encouraged to adopt full accrual-basis IPSAS.

\section{H.1 Countries having good indicators of economic governance are more likely to adopt full accruals-basis IPSAS.}

The second component is defined in terms of debt, coercive pressures and mimetic pressures. Countries with high public debt need foreign aids from international donors. The latter exert coercive pressures to apply IPSAS. Facing these pressures, such countries have an interest in choosing the simplest version of IPSAS to comply with external exigency and at the same time facilitate the implementation of the public accounting system. Pure and modified cash-basis IPSAS are considered as the most trivial forms of the public accounting system.

Countries with high public debt are also making an effort to strengthen their competitive position. For this reason, they need to imitate the successful public accounting system. Since the implementation of pure and modified cash-basis IPSAS forms has more chance to succeed, we propose that such countries are harmonized with cash-basis IPSAS.

\section{H.2 Countries with high coercive and mimetic pressures are more likely to conform to cash-basis IPSAS (pure or modified).}

Likewise, the development of international relationships with the global organization for the accountancy profession (IFAC) and other partners defines a specific axis. In this sense, the third factor, namely "International relationships and exchanges", brings together normative pressures and international trade. Building good relationships with international organizations and in particular with the IFAC encourages countries to refer to the new accounting standards. The IPSAS is considered by the IFAC as an organizational innovation that focuses on accrual accounting choices. Countries need to work in networks of accountants to modernize the accounting institution. Thus, the IFAC's member organizations are interested to introduce accrual accounting following IPSAS standards. Besides, public entities that intend to enter into business relations at an international level 
must deal with the international accounting language based on the accrual accounting model. We can then suppose that:

\section{H.3 Countries having high international relationships and exchanges are more likely to conform to accruals-basis IPSAS (full or modified).}

The fourth factor is composed of both government size and economic growth. Indeed, existing literature shows a causal relationship between these two variables (e.g. Forte \& Magazzino, 2011). In this sense, economic growth can lead to government size increase and vice versa. These characteristics incite governments to transit towards more modern accounting systems such as modified or full accruals-basis IPSAS.

\section{H.4 Countries with a high level of Economic growth and size of government are more likely to adopt accrual-basis IPSAS (full or modified).}

Finally, as mentioned in the literature section, we can also predict that countries having flexible (inflexible) legislative systems opt for modern accounting standards based on accruals (cash) rather on cash (accruals). Besides, the geographical location of a country is a network factor that can justify the choice of the same IPSAS form used by countries belonging to the same region.

\section{H.5 An inflexible legislative system-based countries are more likely to conform to cash-basis IPSAS (pure or modified).}

\section{H.6 Countries located in the same region are more likely to adopt the same form of IPSAS standards.}

\subsection{Multinomial logistic regression model}

Since our dependent variable is a qualitative variable with four modalities, the choice of multinomial logistic regression is the most appropriate choice to test our hypotheses. It is a regression on the qualitative variables and the factors retained from the principal component analysis. We performed this initial logistic regression on the 3 qualitative variables. The two first variables are the geographic region $\left(\mathrm{REG}_{\mathrm{it}-1}\right)$ and the legal system $\left(\mathrm{LEGSYS}_{\mathrm{it}-1}\right)$ that are inherent respectively from the economic network theory and the contingency theory. The third qualitative variable $\left(\mathrm{ACTSYS}_{\mathrm{it}-1}\right)$ is added as a control variable. The latter is linked to the accounting system type. Government entities may opt for several accounting methods depending on each country's legislative framework. Therefore, the adoption of IPSAS (cash basis, modified cash basis, modified accrual-basis, accrual basis) may depend on the accounting method used by public sector entities 
in a country for the preparation of their financial statements (Ben Amor \& Damak Ayadi, 2019). A country in which government entities rely on accrual accounting is not necessarily motivated to adopt the cash-basis IPSAS and vice versa.

In sum, the final model can be stated by the following formulas:

EXT_IPSAS $=\sum \beta_{\mathrm{j}=1}^{\mathrm{i}} * \mathrm{FAC}_{\mathrm{jt}-1}+\alpha_{1} * \mathrm{REG}_{\mathrm{it}-1}+\alpha_{2} * \mathrm{LEGSYS}_{\mathrm{it}-1+} \alpha_{3} * \mathrm{ACTSYS}_{\mathrm{it}-1}+\varepsilon_{\mathrm{it}}$

Where:

EXT_IPSAS: the extent of IPSAS adoption that takes 4 modalities:

1 if the country opts for Cash-basis of IPSAS;

2 if the country opts for Modified cash-basis of IPSAS;

3 if the country opts for Modified accrual-basis of IPSAS;

4 if the country opts for Full accrual-basis of IPSAS.

$\mathrm{FAC}_{\mathrm{jt}-1}$ is the $\mathrm{j}^{\text {th }}$ factor;

Factor 1: Economic governance indicators;

Factor 2: Coercive and mimetic pressures;

Factor 3: International exchanges and relationships;

Factor 4: Economic growth and size of government.

$\beta_{\mathrm{j}}^{\mathrm{i}}$ is the sensitivity of observation (i) to the $\mathrm{j}^{\text {th }}$ factor;

REG: the geographic region which is a nominal qualitative variable measured by belonging to a specific region [1 Latin America and the Caribbean; 2 East Asia and Pacific; 3 South Asia; 4 Sub-Saharan Africa; 5 Middle East and North Africa; 6 Europe and Central Asia; 7 North America];

LEGSYS: the legal system measured by a binary nominal variable: 1 if the country has a common-law legal system and zero otherwise;

ACTSYS: the accounting system type measured by a binary nominal variable: 1 if the country uses accrual accounting system and zero otherwise;

$\varepsilon_{\mathrm{it}}$ is the specific risk of observation (i) at date (t-1).

To identify the impact of the independent variables on the choice of the extent of adoption of IPSAS in N, we take the data relating to $\mathrm{N}-1$.

According to the validity criteria of our econometric model, we test the significance of our model through the Chi-squared Test. A value of this test significant at the $1 \%$ or $5 \%$ level, leads us to reject the null hypothesis and conclude that the model is statistically significant. Besides, we estimate the percentage of a good classification as an indicator of the strength of the model. A high level, exceeding the cut-off of $60 \%$, shows that the model is rather satisfactory. Subsequently, we perform the "Pseudo R-two" Test, which is analog to the R-squared found in OLS. Finally, we check the significance of the impact of the explanatory variables on the variation of the dependent variable by evaluating the estimated coefficient according to the Wald Test. 


\section{Factors influencing the adoption of IPSAS: results and interpretations}

\subsection{Results of descriptive statistics}

The results of the descriptive statistics are summarized in Table 5 in which panel A provides descriptive statistics for quantitative variables. It outlines a large variability of coercive pressures across 84 countries. Indeed, the proportion of foreign aid as a percentage of GDP, which is on average of $3.61 \%$, varies between $0 \%$ and $80 \%$. Regarding normative pressures, the number of national accounting organizations member of IFAC achieves 1.07 on average and does not exceed 5. In terms of mimetic pressures, the percentage of imports represents on average $47.7 \%$ of GDP but it largely varies between $11 \%$ and $161 \%$.

Table 5. Descriptive statistics

\begin{tabular}{lrrrr}
\hline \multicolumn{4}{c}{ Panel A: Descriptive statistics of quantitative variables (87 observations) } \\
\hline \multicolumn{1}{c}{ Variables } & Mean & Minimum & Maximum & $\begin{array}{c}\text { Standard } \\
\text { Deviation }\end{array}$ \\
\hline Coercive pressures (\%) & 3.61 & 0 & 80 & 9.47 \\
Mimetic pressures(\%) & 47.70 & 11 & 161 & 27.48 \\
Normative pressures(\%) & 1.07 & 0 & 5 & 0.73 \\
Economic Growth(\%) & 3.03 & -33 & 14 & 6.64 \\
Corruption & 41.33 & 17 & 90 & 17.21 \\
Inflation(\%) & 5.92 & -1 & 34 & 5.30 \\
Debt(\%) & 47.91 & 6 & 202 & 30.94 \\
International commerce(\%) & -4.49 & -28 & 36 & 9.61 \\
Foreign direct investment(\%) & 9.99 & -1 & 230 & 28.41 \\
Tax pressures(\%) & 17.24 & 1 & 39 & 6.69 \\
Education(\%) & 37.32 & 1 & 89 & 23.89 \\
Size & 139.05 & 2 & 1329 & 195.24 \\
\hline
\end{tabular}

Panel B: Descriptive statistics of qualitative variables (87 observations)

\begin{tabular}{|c|c|c|c|c|}
\hline Variables & Modality & & Number & $\begin{array}{c}\text { Marginal } \\
\text { percentage }\end{array}$ \\
\hline \multirow{3}{*}{$\begin{array}{l}\text { IPSAS } \\
\text { adoption } \\
\text { form }\end{array}$} & $\begin{array}{l}\text { The country opts for IPSAS based on cash } \\
\text { accounting (Cash-basis of IPSAS) }\end{array}$ & 1 & 16 & $18.4 \%$ \\
\hline & $\begin{array}{l}\text { The country chooses cash accounting and } \\
\text { subsequently IPSAS accrual accounting } \\
\text { (Modified cash-basis of IPSAS) }\end{array}$ & 2 & 16 & $18.4 \%$ \\
\hline & $\begin{array}{l}\text { The country opts for accrual accounting } \\
\text { inspired by IPSAS (Modified accruals basis of } \\
\text { IPSAS) }\end{array}$ & 3 & 37 & $42.5 \%$ \\
\hline
\end{tabular}


The transition to IPSAS standards: the extent of adoption and the influence of institutional, contingency and economic network factors

\begin{tabular}{llccc}
\hline & $\begin{array}{l}\text { Country chooses full accrual accounting } \\
\text { following IPSAS (Full accruals basis of } \\
\text { IPSAS) }\end{array}$ & 4 & 18 & $20.7 \%$ \\
\hline & Latin America and The Caribbean & 1 & 12 & $13,8 \%$ \\
& East Asia and Pacific & 2 & 11 & $12.6 \%$ \\
Geographic & South Asia & 3 & 8 & $9.20 \%$ \\
region & Sub-Saharan Africa & 4 & 21 & $24.1 \%$ \\
& Middle East and North Africa & 5 & 8 & $9.2 \%$ \\
& Europe and Central Asia & 6 & 27 & $31 \%$ \\
\hline \multirow{2}{*}{$\begin{array}{l}\text { Legal system } \\
\text { Common law }\end{array}$} & Otherwise & 1 & 5 & $5.7 \%$ \\
\hline $\begin{array}{l}\text { Accounting } \\
\text { system type }\end{array}$ & $\begin{array}{l}\text { Accrual accounting system } \\
\text { Otherwise }\end{array}$ & 0 & 82 & $94.3 \%$ \\
\hline
\end{tabular}

About the network determinants, Panel A exhibits a negative average of the current account balance as a percentage of GDP (an average of $-4.49 \%$ ). A negative current account shows that on average, countries consume and invest more than produce wealth. Moreover, foreign direct investment, net inflows exceed on average $9.99 \%$. This positive average indicates that countries of our sample receive investments more than invest in other economies.

Table 5 reports additional descriptive statistics of the contingency variables. We point out that only $37.32 \%$ of the total population corresponding to the tertiary level education are enrolled. In addition, the gross general government debt can be covered by $47.91 \%$ of GDP. This variable presents a wide difference between their minima and maxima. Besides, the index of corruption averages 41.33 points out of 100. However, the minimum (17 points) and maximum (90 points) values indicate a wide variation within the sample.

Panel B of Table 6 indicates that most countries opt for accrual accounting inspired by IPSAS (37 countries which represent a percentage of $42.5 \%$ ). The other countries are equally shared between the three other forms of IPSAS adoption $(18.4 \%, 18.4 \%$ and $20.7 \%$ for cash-basis, modified cash-basis and full accrualbasis respectively). However, our sample is not equally shared between geographic regions, with a higher proportion in Europe and Central Asia (31\%) and a lower proportion in South Asia and Middle East as well as North Africa (9.2\%). No country in North America has adopted IPSAS. Besides, the civil law legal systemis the most prevalent legal system in our sample ( 82 cases, which presents a percentage of $94.3 \%$ ). Only $24.1 \%$ of cases opt for an accrual accounting system before adopting IPSAS standards. 


\subsection{Analysis of the multinational logistic regression results}

\subsubsection{Correlation coefficients}

Before providing the results of the multinomial logistic regression, we release the correlation analysis between factors identified by the principal component analysis and qualitative variables. First, we provide the Spearman correlation matrix presented in panel A of Table 6. As seen in this Table, the results do not show any significant correlation since all coefficients are less than 0.5 . Thus, they do not indicate a serious problem of multi-collinearity between independent variables. Then, we test the correlation between these factors and qualitative variables that have more than two alternatives (geographic region variable) by the Kruskal-Wallis Test. The results do not show any significant correlation since no coefficients are significant at 5\% level (Panel B of Table 6). Additionally, we use The MannWhitney Test to verify the correlation between our factors and the only qualitative variable that has two alternatives (legal system and accounting system type variables). We do not find any correlation (Panel $\mathrm{C}$ of Table 6). Finally, we examine the relationship between qualitative variables by releasing in pairs employing the Chi-square Test. For all cases, the Chi-square value is not significant at 5\% level (Panel D of Table 6).

Table 6. Results of correlation analysis

Panel A: Results of Spearman correlation matrix

\begin{tabular}{|c|c|c|c|c|c|c|c|}
\hline & FAC 1 & FAC2 & FAC3 & FAC4 & ACTSYS & REG & LEGSYS \\
\hline FAC 1 & 1.000 & & & & & & \\
\hline FAC 2 & 0.158 & 1.000 & & & & & \\
\hline FAC 3 & -0.019 & 0.048 & 1.000 & & & & \\
\hline FAC 4 & $-0.219^{* *}$ & -0.003 & -0.011 & 1.000 & & & \\
\hline ACTSYS & $0.311^{* * * *}$ & -0.203 & 0.102 & -0.113 & 1.000 & & \\
\hline REG & $0.213^{* *}$ & 0.056 & -0.125 & $-0.251^{\text {*** }}$ & 0.046 & 1.000 & \\
\hline LEGSYS & 0.157 & 0.163 & 0.092 & 0.079 & 0.092 & $-0.219^{* *}$ & 1.000 \\
\hline
\end{tabular}

Panel B: Results of Kruskal Wallis Test

\begin{tabular}{lrrrr}
\hline & FAC 1 & FAC2 & FAC3 & \multicolumn{1}{c}{ FAC4 } \\
\hline REG & 6.103 & 8.728 & 5.507 & 9.002 \\
P-value & 0.219 & 0.120 & 0.241 & 0.109 \\
\hline
\end{tabular}

Panel C: Results of the Mann-Whitney Test

\begin{tabular}{lcccc}
\hline & FAC 1 & FAC2 & FAC3 & FAC4 \\
\hline ACTSYS & -1.179 & -0.931 & -.942 & -1.051 \\
P-value & 0.187 & 0.379 & 0.346 & 0.293 \\
LEGSYS & -1.459 & -1.514 & -0.857 & -0.729 \\
P-value & 0.145 & 0.130 & 0.391 & 0.466 \\
\hline
\end{tabular}


Panel D: Results of Chi-square Test

\begin{tabular}{lccc}
\hline & REG & ACTSYS & LEGSYS \\
\hline REG S & 1 & & \\
ACTSYS & 3.722 & 1 & \\
LEGSYS & $10.903^{*}$ & 0.729 & 1 \\
\hline
\end{tabular}

Statistical significance at $* * * 1 \%$ level; $* * 5 \%$ level and $* 10 \%$ level. $\mathrm{FAC}_{\mathrm{it}-1}$ is the $\mathrm{j}^{\text {th }}$ factor; $\beta_{i}^{i}$ is the sensitivity of observation (i) to the $j^{\text {th }}$ factor; REG: geographic region, which is a nominal qualitative variable measured by belonging to a specific region [1 Latin America and the Caribbean; 2 East Asia and Pacific; 3 South Asia; 4 Sub-Saharan Africa; 5 Middle East and North Africa; 6 Europe and Central Asia; 7 North America]; LEGSYS: legal system measured by a binary nominal variable: 1 if the country has a common-law legal system and zero otherwise; ACTSYS: accounting system type measured by a binary nominal variable: 1 if the country uses accrual accounting system and zero otherwise.

\subsubsection{Multinomial logistic regression results}

The results of the multinomial logistic regression are presented in Table 7, retaining first the modified accruals basis IPSAS as a reference choice. We choose this form of adoption as a reference because it is adopted by several countries. Indeed, 37 over 84 countries opt for the modified accruals inspired by IPSAS. Panel A of Table 7 analyses the recourse to the cash-basis of IPSAS compared to the reference choice. Panel B identifies the reasons behind the modified cash-basis of IPSAS choice instead of the reference form. Finally, Panel C contains the results of the logistic model that explain the preference of full accrual-basis of IPSAS instead of modified accruals one.

The model succeeds in explaining $65.4 \%$ of the variance in the level of IPSAS adoption, explained by the predefined variables (see $\mathrm{R}^{2}$ Nagelkerke in Table 7). Besides, the percentage of good classification reaches $64.4 \%$, which indicates that the model is rather satisfactory.

The Chi-square value of 81.137 being significantly positive at the $1 \%$ level allows us to conclude that the model is statistically significant.

As seen in Table 7, the results of estimating the coefficients of this model highlight three main significant results. These results concern the second, the third factors as well as the geographic region variable. All other variables have no significant impact on the extent of IPSAS adoption.

Indeed, Panels A and B show that the statistics of the Wald Test of the third factor are negative and statistically significant at the 5\% level (coefficients of -1.152 and 0.954 respectively for Panels A and B). Our third factor, "International exchanges and relationships", consisting of international trade and normative pressures, therefore significantly and negatively affects the extent of adoption of IPSAS. Precisely, this result indicates that the expansion of the country's international relationships and the diversification of its economic and professional partnerships significantly influence the probability that the country opts for the modified 
accrual-basis of IPSAS rather than the pure or modified cash-basis of IPSAS. Being a member of IFAC and belonging to a network of partners plays a key role in convincing the standards bodies of a country to adopt components of accrualbased IPSAS. Therefore, normative pressures and network effects have a significant positive influence on the use of modified accrual-basis IPSAS. In this way, the third hypothesis is confirmed.

Table 7. Multinomial logistic regressions results (The reference category: Modified accrual-basis IPSAS)

\begin{tabular}{|c|c|c|c|c|c|c|}
\hline \multirow[b]{3}{*}{ Independent variables } & \multicolumn{2}{|c|}{ Panel A } & \multicolumn{2}{|c|}{ Panel B } & \multicolumn{2}{|c|}{ Panel C } \\
\hline & \multicolumn{2}{|c|}{ Cash-basis IPSAS } & \multicolumn{4}{|c|}{$\begin{array}{l}\text { Modified cash-basis Full accrual-basis } \\
\text { IPSAS }\end{array}$} \\
\hline & $\beta$ & Wald-T & $\beta$ & Wald-T & $\beta$ & Wald-T \\
\hline Intercept & -10.074 & 0.000 & -17.155 & 198.359 & -0.122 & 0.004 \\
\hline \multicolumn{7}{|l|}{ PCA Axes } \\
\hline $\begin{array}{l}\text { Factor 1: Economic } \\
\text { governance indicators }\end{array}$ & -0.601 & 1.106 & -.745 & 2.365 & 0.570 & 0.718 \\
\hline $\begin{array}{l}\text { Factor 2: Coercive and } \\
\text { mimetic pressures }\end{array}$ & 0.929 & 1.748 & 1.013 & 2.290 & -1.589 & $2.743 *$ \\
\hline $\begin{array}{l}\text { Factor 3: International } \\
\text { exchanges and relationships }\end{array}$ & -1.152 & $3.770 * *$ & -0.954 & $4.031 * *$ & -0.263 & 0.378 \\
\hline $\begin{array}{l}\text { Factor 4: Economic growth } \\
\text { and size of government }\end{array}$ & -0.592 & 1.543 & -0.252 & 0.349 & 0.529 & 0.626 \\
\hline \multicolumn{7}{|l|}{ Geographical region } \\
\hline $\begin{array}{l}\text { 1-Latin America and the } \\
\text { Caribbean }\end{array}$ & -26.620 & 0.000 & 1.637 & 1.305 & 2.666 & $6.819 * * *$ \\
\hline 2-East Asia and Pacific & 1.145 & 0.574 & 1.019 & 0.717 & 1.608 & 1.593 \\
\hline 3-South Asia & 5.868 & $7.492 * * *$ & 2.417 & 1.704 & -15.123 & 0.000 \\
\hline 4-Sub-Saharan Africa & 2.790 & $5.389 * * *$ & 2.401 & $5.446 * * *$ & 2.690 & $5.686 * *$ \\
\hline $\begin{array}{l}\text { 5-Middle East and North } \\
\text { Africa }\end{array}$ & 0.448 & 0.058 & 0.334 & 0.045 & 0.762 & 0.282 \\
\hline 6-Europe and Central Asia & $0^{\mathrm{c}}$ & & $0^{\mathrm{c}}$ & & $0^{\mathrm{c}}$ & \\
\hline \multicolumn{7}{|l|}{ The accounting system type } \\
\hline Cash accounting system & 23.458 & \multicolumn{2}{|c|}{$0.000-0.628$} & 0.361 & -0.251 & .096 \\
\hline Accrual accounting system & $0^{\mathrm{c}}$ & \multicolumn{2}{|c|}{$0^{\mathrm{c}}$} & \multicolumn{3}{|c|}{$0^{\mathrm{c}}$} \\
\hline $\begin{array}{l}\text { The country's legal system } \\
\text { Legal system other than } \\
\text { Common law } \\
\text { Common law legal system }\end{array}$ & $\begin{array}{r}-15.769 \\
0^{c}\end{array}$ & \multicolumn{2}{|c|}{$\begin{array}{r}0.00014 .710 \\
0^{\mathrm{c}}\end{array}$} & 0.000 & $\begin{array}{r}-2.608 \\
0^{\mathrm{c}}\end{array}$ & 1.592 \\
\hline Chi-square & & $81.137 * * *$ & & & & \\
\hline Nagelkerke $\mathrm{R}^{2}$ & & $65.4 \%$ & & & & \\
\hline Overall $\%$ of good classificat & & $64.4 \%$ & & & & \\
\hline
\end{tabular}

Vol. 19, No. 2 
$*, * *$ and $* * *$ indicate that the coefficient is significant, respectively, at the thresholds of $10 \%, 5 \%$ and $1 \%$.

However, South Asia's countries are not convinced by the importance of applying accrual-based IPSAS. They choose the purely cash-basis accounting category (a positive coefficient of 5.868, statistically significant at the $1 \%$ level). Besides SubSaharan Africa's countries prefer both purely and modified cash basis systems (respectively positive coefficients of 2.790 and 2.401 , statistically significant at the $5 \%$ level). Some of them shift from this form of adoption to the full accrual one and do not use the modified accrual-basis IPSAS (see Panel $\mathrm{C}$ of Table 7 in which, the coefficient of 2.690 is statistically significant at the 5\% level). Latin America and the Caribbean countries are also more likely to choose the full accrual modality rather than the modified one (coefficient of 2.666 statistically significant at the $1 \%$ level). These findings shed the light on the significant role of geographical region as predictors for distinguishing between the reference form and other IPSAS adoption status. Therefore, the last hypothesis (H6) is validated.

Furthermore, Panel $\mathrm{C}$ shows that countries differentiate between the full accrualbasis IPSAS and the reference choice. They prefer the modified accrual one when they are under coercive or mimetic pressures. Indeed, the likelihood of adopting the full accrual-basis IPSAS compared to the reference form is negatively and significant at the $10 \%$ level (coefficient of -1.589). Under these pressures and between the two modalities of accrual-basis accounting, countries choose the trivial form. When the country's standards bodies are not convinced of the benefits of accruals and are obliged to follow international recommendations, they opt for the simplest category.

To better understand the country's decision about the form of IPSAS adoption, we, hereafter, conduct a multinomial logistic regression, retaining the full accrual-basis IPSAS as a pivot. Table 8 provides the results of these regressions.

Table 8. Multinomial logistic regressions results (The reference category: full accrual-basis IPSAS)

\begin{tabular}{lrrrr}
\hline & \multicolumn{2}{c}{ Panel A } & \multicolumn{2}{c}{ Panel B } \\
\hline \multicolumn{1}{c}{ Independent variables } & Cash-basis IPSAS & \multicolumn{2}{c}{$\begin{array}{c}\text { Modified cash- } \\
\text { basis IPSAS }\end{array}$} \\
\hline Intercept & $\beta$ & Wald-T & \multicolumn{1}{c}{$\beta$} & Wald-T \\
\hline PCA Axes & -9.953 & 0.000 & -17.033 & 117.078 \\
Factor 1: Economic governance indicators & & & & \\
Factor 2: Coercive and mimetic pressures & -1.171 & 2.173 & $\mathbf{- 1 . 3 1 6}$ & $\mathbf{3 . 1 9 2 *}$ \\
Factor 3: International exchanges and relationships & -0.889 & 1.766 & -0.690 & 1.516 \\
Factor 4: Economic growth and size of government & -1.122 & 2.248 & -0.782 & 1.204 \\
\hline
\end{tabular}




\begin{tabular}{|c|c|c|c|c|c|}
\hline \multicolumn{6}{|l|}{ Geographical region } \\
\hline 1-Latin America and the Caribbean & & -29.286 & 0.000 & -1.028 & 0.453 \\
\hline 2-East Asia and Pacific & & -0.462 & 0.063 & -0.589 & 0.139 \\
\hline 3-South Asia & & 20.991 & 0.000 & 17.539 & 0.000 \\
\hline 4-Sub-Saharan Africa & & 0.100 & 0.005 & -0.288 & 0.052 \\
\hline 5-Middle East and North Africa & & -0.314 & 0.020 & -0.428 & 0.045 \\
\hline 6-Europe and Central Asia & & $0^{c}$ & & $0^{\mathrm{c}}$ & \\
\hline \multicolumn{6}{|l|}{ The accounting system type } \\
\hline Cash accounting system & & 23.709 & 0.000 & 0.879 & 0.616 \\
\hline Accrual accounting system & & $0^{\mathrm{c}}$ & & $0^{\mathrm{c}}$ & \\
\hline \multicolumn{6}{|l|}{ The country's legal system } \\
\hline Legal system other than Common law & & -13.161 & 0.000 & 17.318 & 0.000 \\
\hline Common law legal system & & $0^{c}$ & & $0^{\mathrm{c}}$ & \\
\hline Chi-square & $81.137 * * *$ & & & & \\
\hline Nagelkerke $\mathrm{R}^{2}$ & $65.4 \%$ & & & & \\
\hline Overall \% of good classification & $64.4 \%$ & & & & \\
\hline
\end{tabular}

The results summarized in Table 8 reinforce the previous findings that underline the importance of coercive and mimetic pressures in choosing the simplest version of IPSAS adoption. As shown in Panels A and B of Table 8, the probability of implementing purely or modified cash-basis IPSAS instead of full accruals one is significantly influenced by the coercive and mimetic pressures. Indeed, the positive coefficients of 2.518 and 2.601 are statistically significant at the 5\% level. In this sense, we can confirm the second hypothesis.

Panel B also reveals that the main factor pushing countries to opt for full accrualbasis IPSAS rather than modified cash one is the level of good governance of countries. The good country governance is associated with the likelihood of adopting the full accrual-basis IPSAS (negative coefficient of 1.316 statistically significant at the $10 \%$ level). Countries with good governance indicators are moving towards full adoption of IPSAS. This form reinforces accountability and helps governments in the improvement of their transparency and the promotion of effective employment of public resources. Hence, our first hypothesis on the good governance factor is validated.

However, the fourth factor about the economic growth and the country size is not an important determinant since no corresponding coefficient is significant at the $10 \%$ level. So, the fourth hypothesis is not verified. Besides, the coefficient of the "country's accounting system" variable is not significant at the $10 \%$ level in any regression. Therefore, this control variable does not affect the choice of the IPSAS adoption category. The familiarity of IPSAS standards with accrual accounting 
does not push governments towards the same form of the accounting system. Finally, unlike Ben Amor and Damak Ayadi (2019) who found that the adoption of IPSAS is stronger in countries with flexible legislative systems, our results show that a flexible legislative system has not any significant impact on the extent of IPSAS adoption. The fact that only 5 over 87 countries have flexible legal system based on "Common Law" may explain the insignificant coefficient for this variable. So, our fifth hypothesis is not verified.

\section{Discussion and conclusion}

In this research, we studied the variability of the extent of IPSAS adoption and we have identified four principal factors behind these differences. By identifying 4 forms of adoption of these standards and through a principal component analysis and multinomial logistic regressions, our results show that the choice of adoption of IPSAS category is conditioned by institutional, contingency and network factors. Indeed, coercive and mimetic pressures have a significant positive effect on the adoption of cash-basis IPSAS.

The government's need for foreign international financial aids and the desire to imitate the successful experiences compel them to embark on IPSAS reforms. Consequently, the institutional theory, which emphasizes the search for legitimacy, was relatively well supported by our results. Nevertheless, these governments prefer the cash form of adoption that is considered as the more appropriate form of an accounting system for them. Indeed, the orientation towards more sophisticated status such as accrual-basis IPSAS requires systems with strength integrated accounts and "data processing within the central administration" and this limits the chance of its successful implementation.

Countries that need to renegotiate their debts suffer from coercive pressures exerted by international finance organizations. Nevertheless, such pressures were not strong enough to change their political to accrual-basis IPSAS. South Asia and Sub-Saharan Africa's countries are the most governments that decide to adopt the purely or modified cash-basis IPSAS. These forms of adoption became the more appropriate alternative for less developed countries that suffer from lacking fundamental acknowledge in accounting regulations and standards (Adhikari \& Mellemvik, 2010).

Unlike previous studies that identified the coercive and mimetic pressures as the main factor of the adoption of IPSAS standards (Abushamsieh et al., 2014; Christiaens et al., 2014; Sellami \& Gafsi, 2019), our research reveals that this association is true only when considering the low level of adoption. These findings may be useful for international lending institutions when providing their recommendations about the application of IPSAS standards. Considering the 
geographic location of a country and its social-political context may improve the recommendations of these organizations about the appropriate form that should be adopted.

Furthermore, our results highlight that the countries moving to modified accrual-basis IPSAS are those having close working relationships with several development partners. Maintaining good international exchanges and relationships is a key stimulus influencing governments to introduce more elements of accruals following IPSAS standards. Their collaboration with accounting professional bodies also facilitates information exchange by diffusing more sophisticated accounting practices among government accountants. Such professional networks enhance the development of accrualbased IPSAS. In this sense, our research is the first to identify the positive influence of the economic network on the extent of IPSAS adoption. According to the principle of economic network theory, modified accrual-basis IPSAS can be a product with a "network effect".

Finally, our findings prove that the transition to full accrual-based IPSAS only aims to gain good governance. Because this kind of IPSAS adoption increases accountability and "fiscal information" transparency of government, some countries apply the full adoption. However, only a few number of them choose this alternative. Precisely, some Sub-Saharan Africa's countries leave the cashbased IPSAS to move towards full accrual one. Besides, Latin America and the Caribbean countries are mainly full accrual-based IPSAS adopters. The fight against corruption motivates this choice since the full accrual accounting provides more comparable and comprehensive information than those diffused by the cash accounting. Reforms of the public sector towards full accrualbased IPSAS then promote good government governance. It therefore seems that the factors of a full transition to IPSAS-accrual accounting, like corruption, fiscal transparency, education or inflation, are more supported by the contingency theory than institutional theory. Such indicators of a country's economic governance that are not profoundly examined by previous studies better explain the choice of accrual-based IPSAS adoption.

These results are relevant to several parties. Researchers that can assist government regulatory authorities should be aware of the factors that determine the appropriate form of IPSAS that may be implemented by nonadopting countries. International financial lenders should be also conscious of the determinants behind each level of IPSAS adoption to suggest recommendations that are more applicable by countries.

Despite the conceptual, empirical and practical contributions of this research, it has limits, which may be essential to the opening of future debates. First, only 84 countries were included in the study due to data availability issues. Besides, this study overlooks other factors that may influence the decision to adopt IPSAS, such 
as the political factor, the IFRS adoption. Furthermore, as underlined by (Adhikari et al., 2015), the adoption of the IPSAS standards does not necessarily lead to the implementation of these standards in their specific environments. Under some pressures, governments accept the adoption of IPSAS standards under a specific form but try to delay their implementation. Further research should explore the evolution of the implementation of these standards and the reasons behind this delay.

\section{References}

Abushamsieh, K. Hernández, A.M.L. \& Ortiz-Rodríguez, D. (2014) "Le renforcement de la transparence de la comptabilité publique dans certains pays arabes", Revue Internationale des Sciences Administratives, vol. 80, no. 2: 461-482

ACCA (2017) "IPSAS Implementation: Current Status and Challenges", available on-line at https://www.accaglobal.com/content/dam/ACCA_Global/ Technical/pubsect/pi-IPSAS-implementation-current-status-andchallenges.pdf

Adhikari, P. \& Mellemvik, F. (2010) "The adoption of IPSASs in South Asia: A comparative study of seven countries", In Research in Accounting in Emerging Economies: 169-199

Adhikari, P., Kuruppu, C., Wynne, A.\& Ambalangodage, D. (2015) "Diffusion of the Cash Basis International Public Sector Accounting Standard (IPSAS) in less developed countries (LDCs) - The case of the Nepali central government", Research in Accounting in Emerging Economies, vol. 15: $85-108$

Ali, M.J. (2005) "A synthesis of empirical research on international accounting harmonization and compliance with international financial reporting standards", Journal of Accounting Literature, vol. 24, no. 1: 1-52

Argento, D., Peda, P. \& Grossi, G. (2018) "The enabling role of institutional entrepreneurs in the adoption of IPSAS within a transitional economy: The case of Estonia", Public Administration and Development, vol. 38, no. 1: 39-49

Atuilik, W. A. (2016) "The relationship between the adoption of international public sector accounting standards (IPSAS) by governments and perceived levels of corruption", International Journal of Current Research, vol. 8, no. 5: 32052-32070

Babatunde, S.A. (2013) "The effects of adoption of accrual-based budgeting on transparency and accountability in the Nigerian public sector", International Journal of Governmental Financial Management, vol. 15, no. $1: 15-35$

Ball, I. (2012) "New development: transparency in the public sector", Public Money \& Management, vol. 32, no. 1: 35-40 
Ben Amor, D. \& Damak Ayadi, S. (2019) "The profile of IPSAS-adopters", Accounting and Management Information Systems, vol. 18, no. 2: 262-282

Benito, B., Bastida, F. \& García, J. A. (2010) "Explaining differences in efficiency: an application to Spanish municipalities", Applied Economics, vol. 42, no. 4: $515-528$

Benito, B., Bastida, F. \& García, J. A. (2010) "The determinants of efficiency in municipal governments", Applied Economics, vol. 42, no. 4: 515-528

Benito, B., Brusca, I. \& Montesinos, V. (2007) "The harmonization of government financial information systems: The role of IPSAS", International Review of Sciences Administration, vol. 73, no. 2: 323-350

Brusca, I. \& Martínez, J. (2016) "L'adoption des IPSAS : un défi pour la modernisation et l'harmonisation de la comptabilité du secteur public", Revue Internationale des Sciences Administratives, vol. 82, no. 4: 761-781

Brusca, I., Montesinos, V. \& Chow, D. S. L. (2013) "Legitimating international public sector accounting standards (IPSAS): The case of Spain", Public Money \& Management, vol. 33, no. 6: 437-444

Caba, C., López, A. \& Ortiz, D. (2009) "Governmental financial information reforms and changes in the political system: the Argentina, Chile and Paraguay experience", Public Administration and Development, vol. 29, no. 5: 429-440

Chan, J.L. \& Rubin, M.A. (1987) "The role of information in a democracy and in government operations", Research in Governmental and Nonprofit Accounting, vol. 3, no. 4: 3-27

Chan, J.L. (2006) "IPSAS and government accounting reform in developing countries", Accounting reform in the public sector: mimicry, fad or necessity: 31-42.

Chan, J.L., Jones, R.H. \& Lüder, K.G. (1996) "Modeling Governmental Accounting Innovations: An Assessment and Future", Research Directions Research in Governmental Nonprofit Accounting, vol. 9: 1-19

Christiaens, J., Reyniers, B. \& Rollé, C. (2010) "Impact of IPSAS on reforming governmental financial information systems: a comparative study", International Review of Administrative Sciences, vol. 76, no. 3: 537-554

Christiaens, J., Vanhee, C., Manes-Rossi, F., Aversano, N. \& Van-Cauwenberge, P. (2014) "The effect of IPSAS on reforming governmental financial reporting: An international comparison", International Review of Administrative Sciences, vol. 81, no. 1: 158-177

Clements, C.E., Neill, J.D. \& Stovall, O.S. (2010) "Cultural diversity, country size, and the IFRS adoption decision", Journal of Applied Business Research, vol. 26 , no. 2 : $115-126$

Cohen, S., Karatzimas, S. \& Venieris, G. (2015) "The informative role of accounting standards in privatising state-owned property: comparing Greek Governmental Accounting Standards and IPSAS", Global Business and Economics Review, vol. 17, no. 1: 51-62 
DiMaggio, P.J. \& Powell, W.W. (1983) "The iron cage revisited: Institutional isomorphism and collective rationality in organizational fields", American Sociological Review, vol. 48, no. 2: 147-160

Downes, A.S. \& Mamingi, N. (2001) "The Measurement of Country Size and Implications for the Survival of Small States in the Global Economy", ECCBs Fifth Annual Conference on Development. 2001

Forte, F. \& Magazzino, C. (2011) "Optimal Size Government and Economic Growth in EU Countries", EconomiaPolitica, vol. 28, no. 3: 295-321

Grossi, G. \& Soverchia, M. (2011) "European Commission adoption of IPSAS to reform financial reporting", Abacus, vol. 47, no. 4: 525-552

Hamisi, K.S. (2012) "The factors affecting the implementation of IPSAS in Kenya”, Unpublished MBA project, University of Nairobi, available online http://erepository.uonbi.ac.ke/bitstream/handle/11295/13168/Hamisi_The $\% 20$ factors $\% 20$ affecting $\% 20$ the $\% 20$ implementation $\% 20$ of $\% 20$ internation al\%20public\%20sector\%20accounting\%20standards\%20in\%20Kenya.pdf? sequence $=3 \&$ is Allowed $=y$

International Federation of Accountants (IFAC, 2012). PAO Global Development Report. New York: IFAC, available on-line at http://www.ifac.org/sites/ default/files/publications/files/GDR\%20Report_0.pdf [Accessed 21 December 2019].

Izedonmi, F. \& Ibadin, P. (2013) "International Public Sector Accounting Framework, Regulatory Agencies and Standard Setting Procedures: A Critique", European journal of business and management, vol. 5, no. 6: $17-24$

Javed, M. \& Zhuquan, W. (2018) "Analysis of Accounting Reforms in the Public Sector of Pakistan and Adoption of Cash Basis IPSAS", Universal Journal of Accounting and Finance, vol. 6, no. 2: 47-53

Jorge, S., Brusca, I. \& Nogueira, S. P. (2019) "Translating IPSAS into national standards: An illustrative comparison between Spain and Portugal", Journal of Comparative Policy Analysis: Research and Practice, vol. 21, no. 5: 445-462

Judge, W., Li, S. \& Pinsker, R. (2010) "National adoption of international accounting standards: An institutional perspective", Corporate Governance: An International Review, vol. 18, no. 3: 161-174

Kartiko, S.W., Rossieta, H., Martani, D. \& Wahyuni, T. (2018) "Measuring accrual-based IPSAS implementation and its relationship to central government fiscal transparency", Brazilian Administration Review, vol. 15, no. $4: 1-28$

Kossentini, A. \& Ben Othman, H. (2014) "A study of the institutional and economic determinants of IFRS adoption in emerging economies", TIJA Symposium TIJA, V.K. Zimmerman Center for International Education \& Research in Accounting, the University of Illinois at Urbana-Champaign 
Lapsley, I. (1999) "Accounting and the New Public Management: Instruments of substantive efficiency or a rationalising modernity", Financial Accountability \& Management, vol. 15, no. 3-4: 201-207

Lau, A. \& Ma, R. (1997) "A broad perspective on Financial Reporting in the Pacific Asia", Financial reporting in the Pacific Asia region world scientific: accounting and business in Asia. World Scientific Publishing, Singapore: 55-92, available on-line at https://books.google.tn/books?hl=fr\&lr=\&id=-

$\mathrm{Q} 3 \mathrm{tCgAAQBAJ} \&$ oi $=$ fnd \&pg $=\mathrm{PA} 55 \& \mathrm{dq}=\% 22 \mathrm{~A}+$ broad + perspective + on $+\mathrm{F}$ inancial+Reporting+in+the+Pacific+Asia\%22\&ots=hMFStCT8H\&sig=TbzeyGlexRgODf09sJkYqE3LMBQ\&redir_esc $=\mathrm{y} \# \mathrm{v}=$ onepage $\& \mathrm{q}=$ $\% 22 \mathrm{~A} \% 20 \mathrm{broad} \% 20$ perspective\%20on\%20Financial\%20Reporting\%20in $\% 20$ the $\% 20$ Pacific $\% 20$ Asia\% $22 \& \mathrm{f}=$ false

Lüder, K. (1992) "Contingency model of governmental accounting innovations in the political-administrative environment", Research in Governmental and Nonprofit Accounting (RIGNA), vol. 7: 99-127

Meyer, J.W. \& Rowan, B. (1977) "Institutionalized organizations: formal structure as myth and ceremony", American Journal of Sociology, vol. 83, no. 2: 340-363

Mhaka, C. (2014) "IPSAS, a guaranteed way of quality government financial reporting? A comparative analysis of the existing cash accounting and IPSAS based accounting reporting", International Journal of Financial Economics, vol. 3, no. 3: 134-141

Miraj, J. \& Wang, Z. (2018) "Adoption of International Public Sector Accounting Standards in public sector of developing economies-analysis of five South Asian countries", Research in World Economy, vol. 9, no. 2: 44-51

Ndinga, M.M.A. (2002) "La gouvernance économique: quelles incidences sur le développement au Congo-Brazzaville", Africa Development /Afrique et Développement, vol. 27, no. 1\&2: 1-24

Opanyi, R.O. (2016) "The effect of adoption of International Public Sector Accounting Standards on quality of financial reports in public sector in Kenya”, European Journal of Scientific Research, vol. 12, no. 28: 161-187

Ouda, H. (2004) "Basic requirements model for successful implementation of accrual accounting in the public sector", Public Fund Digest, vol. 4, no. 1: 78-99

Ouda, H. (2010) "A prescriptive model for successful transition to accrual accounting in the government sector", International Journal on Governmental Financial Management, vol. 10, no. 1

Pilcher, R. (2011) "Implementing IFRS in local government institutional isomorphism as NPM goes mad?", Local Government Studies, vol. 37, no. 4: 367-389

Pina, V. \& Torres, L. (2003) "Reshaping public sector accounting: an international comparative view", Canadian Journal of Administrative Sciences/Revue Canadienne des Sciences de l'Administration, vol. 20, no. 4: 334-350 
Rajib, S.U., Adhikari, P., Hoque, M. \& Akter, M. (2019) "Institutionalisation of the cash basis International Public Sector Accounting Standard in the central government of Bangladesh: An example of delay and resistance", Journal of Accounting in Emerging Economies, vol. 9, no. 1:28-50

Rakoto, H.O. \& Lande, E. (2008) "Légitimité et applicabilité des normes comptables internationales: le cas de Madagascar", Conference Paper, 29th AFC Congress in Cergy, available on-line at https://halshs.archivesouvertes.fr/halshs-00525400/document

Ramanna, K. \& Sletten, E. (2014) "Network effects in countries' adoption of IFRS", The Accounting Review, vol. 89, no. 4: 1517-1543

Ramanna, K. \& Sletten, E. (2009) "Why do countries adopt international financial reporting standards?", Harvard Business School, Working paper, 09-102, Retrieved from: http://www.hbs.edu/faculty/Publication\%20Files/09-102. pdf

Rossi, M., Aversano, F. \& Christiaens, J. (2014) “IPSASB's conceptual framework: coherence with accounting systems in european public administrations", International Journal of Public Administration, vol.37, no. 8: $456-465$

Scheid, J.C. (2006) "Accounting Reform in the Public Sector: Mimicry, Fad or Necessity", Paris. Experts Comptables Media: 31-42

Sellami, Y.M. \& Gafsi, Y. (2019) "Institutional and economic factors affecting the adoption of international public sector accounting standard", International Journal of Public Administration, vol. 42, no. 2: 119-131

Shima, K.M. \& Yang, D.C. (2012) "Factors affecting IFRS adoption", International Journal of Business, vol. 17, no. 3: 276-298

Sour, L. (2012) "IPSAS and government accounting reform in Mexico", International Journal of Public Sector Performance Management, vol. 2, no.1: 5-24

Sutcliffe, P. (2003) "The Standards Programme of IFAC's Public Sector Committee", Public Money and Management, vol.23, no. 1: 29-36

Tanjeh, M.S. (2016) "Factors influencing the acceptation of International Public Sector Accounting Standards in Cameroon", Accounting and Finance Research, vol. 5, no. 2: 71-83 
Appendix A: The extent of IPSAS adoption by country

\begin{tabular}{|c|c|c|c|c|c|c|c|}
\hline \multicolumn{2}{|c|}{$\begin{array}{l}\text { 1. Cash-basis } \\
\text { of IPSAS }\end{array}$} & \multicolumn{2}{|c|}{$\begin{array}{l}\text { 2.Modified cash- } \\
\text { basis of IPSAS }\end{array}$} & \multicolumn{2}{|c|}{$\begin{array}{c}\text { 3. Modified } \\
\text { accruals-basis } \\
\text { of IPSAS }\end{array}$} & \multicolumn{2}{|c|}{$\begin{array}{l}\text { 4. Full accruals-basis } \\
\text { of IPSAS }\end{array}$} \\
\hline Year & Country & Year & Country & Year & Country & Year & Country \\
\hline 2006 & Bangladesh & 2010 & Botswana & 2008 & Armenia & 2007 & Barbados \\
\hline 2014 & Bhutan & 2012 & Cambodia & 2014 & Austria & 2013 & Cayman Isl \\
\hline 2009 & Fiji & 2009 & Georgia & 2004 & Azerbaijan & 2015 & Chile \\
\hline 2004 & Iraq & 2003 & India & 2004 & Bosnia \&Her & 2015 & Colombia \\
\hline 2004 & Kosovo & 2015 & Jordon & 2008 & Brasil & 2016 & Dominican \\
\hline 2005 & Madagascar & 2014 & Kenya & 2016 & Costa Rica & 2016 & Ecuador \\
\hline 2005 & Malaysia & 2010 & Lesotho & 2013 & Cyprus & 2004 & Estonia \\
\hline 2018 & Namibia & 2009 & Liberia & 2010 & Czech & 2014 & Ghana \\
\hline 2009 & Nepal & 2002 & Macedonia & 2013 & Guatemala & 2014 & Honduras \\
\hline 2001 & Pakistan & 2010 & Montenegro & 2013 & Hungary & 2010 & Indonesia \\
\hline 2003 & Serbia & 2014 & Nigeria & 2003 & Indonesia & 2013 & Kazakhstan \\
\hline 2012 & Seychelles & 2008 & Rwanda & 2004 & $\underline{\text { Israel }}$ & 2011 & $\underline{\text { Malta }}$ \\
\hline 2016 & $\underline{\text { Sierra Leone }}$ & 2003 & Tanzania & 2002 & Jamaica & 2011 & Mauritius \\
\hline 2002 & Sri Lanka & 2014 & Uganda & 2008 & Kuwait & 2016 & Nigeria \\
\hline 2008 & Zambia & 2012 & Uruguay & 2013 & $\underline{\text { Lao PDR }}$ & 2014 & Panama \\
\hline \multirow[t]{18}{*}{2012} & Zimbabwe & & & 2014 & Latvia & 2011 & Peru \\
\hline & & & & 2010 & Lithuania & 2019 & Saudi Arabia \\
\hline & & & & 2015 & Malaysia & 2008 & Switzerland \\
\hline & & & & 2015 & $\underline{\text { Moldova }}$ & 2012 & Tanzania \\
\hline & & & & 2014 & Mongolia & & \\
\hline & & & & 2007 & Morocco & & \\
\hline & & & & $\begin{array}{l}2010 \\
2014\end{array}$ & $\begin{array}{l}\text { New Zealand } \\
\text { Philippine }\end{array}$ & & \\
\hline & & & & 2015 & Portugal & & \\
\hline & & & & 2011 & Romania & & \\
\hline & & & & 2014 & Russia & & \\
\hline & & & & 2005 & Senegal & & \\
\hline & & & & 2015 & Slovakia & & \\
\hline & & & & 2008 & South Africa & & \\
\hline & & & & 2002 & Spain & & \\
\hline & & & & 2016 & Sri Lanka & & \\
\hline & & & & 2010 & Thailand & & \\
\hline & & & & 2017 & Tunisia & & \\
\hline & & & & 2013 & Turkey & & \\
\hline
\end{tabular}

Vol. 19, No. 2 
The transition to IPSAS standards: the extent of adoption and the influence of institutional, contingency and economic network factors

\begin{tabular}{lccc}
\hline $\begin{array}{c}\text { 1. Cash-basis } \\
\text { of IPSAS }\end{array}$ & $\begin{array}{c}\text { 2.Modified cash- } \\
\text { basis of IPSAS }\end{array}$ & $\begin{array}{c}\text { 3. Modified } \\
\text { accruals-basis } \\
\text { of IPSAS }\end{array}$ & $\begin{array}{c}\text { 4. Full accruals-basis } \\
\text { of IPSAS }\end{array}$ \\
& 2006 & Ukraine \\
& 2002 & $\underline{\text { United }}$ \\
& 2009 & Uzbekistan \\
\hline
\end{tabular}

Appendix B: A summary table of variables, measurement and data sources

\begin{tabular}{|c|c|c|}
\hline Variables & Measures & Data sources \\
\hline EXT-IPSAS & $\begin{array}{l}\text { extent of IPSAS adoption: Ordinal variable } \\
\text { measured as follows: } \\
1 \text { if the country opts for IPSAS based on cash } \\
\text { accounting; } \\
2 \text { if the country chooses cash accounting and } \\
\text { subsequently accrual accounting inspired } \\
\text { by IPSAS; } \\
3 \text { if the country opts for accrual accounting } \\
\text { inspired by IPSAS; } \\
4 \text { if the country opts for all accrual accounting } \\
\text { following IPSAS. }\end{array}$ & $\begin{array}{l}\text { Authors through } \\
\text { IFAC's, ACCA's, } \\
\text { PWH's, EY's, } \\
\text { Deloitte's, World } \\
\text { Bank's and African } \\
\text { Development } \\
\text { bank's, Ministries } \\
\text { of } \quad \text { Finance } \\
\text { websites and other } \\
\text { secondary sources }\end{array}$ \\
\hline COER_PRES & $\begin{array}{l}\text { Proportion of foreign aid as a percentage of } \\
\text { GDP }\end{array}$ & World Bank website \\
\hline MIM_PRES & Percentage of imports as a percentage of GDP & World Bank website \\
\hline NORM_PRES & $\begin{array}{l}\text { Number of national accounting organizations } \\
\text { member of IFAC }\end{array}$ & $\begin{array}{l}\text { Authors through } \\
\text { IFAC websites and } \\
\text { websites of IFAC } \\
\text { members }\end{array}$ \\
\hline GROWTH & economic growth as a percentage of GDP & World Bank website \\
\hline COR & $\begin{array}{l}\text { corruption perception index (CPI): a scale of } 0 \\
\text { to } 100.0 \text { indicates a high corruption level and } \\
100 \text { a very low level. }\end{array}$ & $\begin{array}{l}\text { Transparency } \\
\text { International website }\end{array}$ \\
\hline INFL & $\begin{array}{l}\text { annual percentage change in a Consumer Price } \\
\text { Index }\end{array}$ & World Bank website \\
\hline DEBT & $\begin{array}{l}\text { gross general government debt, as a percentage } \\
\text { of GDP }\end{array}$ & IFM website \\
\hline INT_T & $\begin{array}{l}\text { current account balance as a percentage of } \\
\text { GDP }\end{array}$ & IFM website \\
\hline FOREIGN_INV & $\begin{array}{l}\text { foreign direct investment, net inflows as a } \\
\text { percentage of GDP }\end{array}$ & World Bank website \\
\hline
\end{tabular}




\begin{tabular}{|c|c|c|}
\hline Variables & Measures & Data sources \\
\hline FISC_PRES & tax revenues as a percentage of GDP & World Bank website \\
\hline GEOG & $\begin{array}{l}\text { multiple dummy variable coded from } 1 \text { to } 7 \text { as } \\
\text { follows: } 1 \text { Latin America and the Caribbean; } 2 \\
\text { East Asia and Pacific; } 3 \text { South Asia; } 4 \text { Sub- } \\
\text { Saharan Africa; } 5 \text { Middle East and North } \\
\text { Africa; } 6 \text { Europe and Central Asia; } 7 \text { North } \\
\text { America }\end{array}$ & World Bank website \\
\hline EDUC & $\begin{array}{l}\text { total enrollment divided by the total population } \\
\text { of the age group }\end{array}$ & World Bank website \\
\hline SIZE & population density per $\mathrm{km}^{2}$ & World Bank website \\
\hline LEGSYS & $\begin{array}{l}\text { binary nominal variable: } 1 \text { if the country has a } \\
\text { common-law legal system and zero otherwise }\end{array}$ & $\begin{array}{l}\text { World } \\
\text { website }\end{array}$ \\
\hline
\end{tabular}

\footnotetext{
${ }^{\mathrm{i}}$ Cash basis IPSAS: "According to IFAC, cash basis of accounting is a 'basis of accounting that recognizes transactions and other events only when cash is received or paid' (IFAC, 2008: 926) It measures financial results for a period as the difference between cash receipts and cash payments. Cash flow statements and cash balances are the most common documents".

ii ACCA: The Association of Chartered Certified Accountants.

iii PricewaterhouseCoopers website (PWH, 2015) and Deloitte's IAS-plus webpage (2013).

iv World Bank's and African Development bank's websites.
} 